\title{
Is the Korean Innovation of Individual Informant Rewards a Viable Cartel Detection Tool?
}

\author{
Andreas Stephan \\ ESRC Centre for Competition Policy \& \\ Norwich Law School \\ University of East Anglia \\ CCP Working Paper 14-3
}

\begin{abstract}
This paper considers whether the use of individual informant rewards or bounties is a viable cartel detection tool. Rewards have the potential to enhance enforcement by revealing infringements that would otherwise go undetected. In order to be effective they should be made available to individuals directly involved in cartels because they may be the only viable source of information. Mere protection from retaliatory measures of employers does not create an adequate incentive to report misbehaviour. The personal costs and risks associated with whistleblowing are so significant that effective rewards may need to amount to a lottery win in order for reporting to be worthwhile. Reward systems pose some dangers to the enforcement system, but these can be managed.
\end{abstract}

Contact Details:

Andreas Stephan

a.stephan@uea.ac.uk 


\title{
Is the Korean Innovation of Individual Informant Rewards a Viable Cartel Detection Tool?
}

\author{
Andreas Stephan*
}

This is a draft of a book chapter due to be published in: T Cheng, B Ong, and S Marco Colino, Cartels in Asia (Kluwer 2014)

\section{Introduction}

The defining characteristic of modern cartel enforcement is the use of leniency prog rammes. This innovation, first employed by the US in the late 1970s, has been emulated by the vast majority of competition law enforcement regimes around the world. They share the basic principle of offering immunity to the first firm (and where applicable its employees) to report a cartel infringement to the competition authority. It is thought leniency prog rammes have been instrumental in destabilising and uncovering cartel infringements, thereby undermining the trust that exists between cartel members and increasing the rate at which cartels are detected. The US Department of Justice has said leniency provides 'unparalleled information from cartel insiders about the origins and inter-workings of secretive cartels' ${ }^{1}$

Despite the offer of leniency and the increasing levels of fines imposed on cartels, competition authorities continue to uncover a high volume of infringements. This might suggest that more could be done to strengthen deterrence in cartel enforcement by either increasing sanctions or raising the probability of detection. Corporate fines will soon reach a plateau where either political pressure or firms' inability to pay will prevent them from increasing any further. There is a question of whether fines ever actually exceed the illegal profits earned through cartel infringements, or directly punish the individuals responsible. This has caused an increasing number of jurisdictions to adopt criminal offences against individuals and other alternative sanctions, for instance director disqualifications. However, such complementary sanctions can be hard to implement and effectively enforce, as compared to corporate sanctions (especially in an administrative or civil enforcement

\footnotetext{
* Professor of Competition Law, ESRC Centre for Competition Policy and UEA Law School, University of East Anglia, Norwich NR4 7TJ, UK. Email:a.stephan@uea.ac.uk

${ }^{1}$ SD Hammond, (US Department of Justice, Antitrust Division), 'The Evolution of Antitrust Enforcement over Two Decades'. Speech at $24^{\text {th }}$ National Institute on White Collar Crime, Miami, Florida. 25 February 2010.
} 
system). ${ }^{2}$ Even leniency programmes have one serious limitation; the cooperating parties are themselves directly involved in the illegality, raising the possibility that leniency could be used strategically. For example, one study has suggested that leniency applications in the EU are generally made after the cartel has failed, which may imply the motivation for coming forward is a desire to gain a competitive advantage through the enforcement system. ${ }^{3}$

It has been suggested that the 'next logical step' in advancing antitrust enforcement may be the use of rewards or bounties to individual whistleblowers. ${ }^{4}$ These are individuals who are aware of an infringement but are not necessarily directly involved in it. In return for a reward, they will ostensibly make the competition authority aware of an undetected infringement or help them build a more effective case against an infringement they are already aware of. South Korea has the distinction of being the first jurisdiction to have introduced an informant reward system and is therefore the innovator of this latest addition to the cartel enforcement toolkit. Cartel whistleblower reward systems have also been introduced by a handful of other jurisdictions, but some - most notably the United States have chosen to reject such a system.

Beyond leniency programmes, whistleblowing has long played a key role in uncovering corporate misbehaviour. For example, Sherron Watkins and Cynthia Cooper are thought to have been instrumental in uncovering large scale fraud at Enron and WorldCom. ${ }^{5}$ This Chapter also discusses a number of examples of whistleblowing in the context of competition policy, including the infamous FBI informant Mark Whitacre. Yet despite the potential value of corporate whistleblowers, they have generally received no reward from the authorities. Nor have they enjoyed adequate protections from the retaliatory actions of their employers, or the wider consequences for their careers and personal lives. Following the plethora of large financial scandals in the last fifteen years, there appears to be growing recognition of the value of informants. In 2002, Time magazine named Watkins and Cooper as 'Persons of the Year' in recognition of their role in uncovering the corporate misbehaviour. ${ }^{6}$ More recently, a 2011 study prepared by the OECD for the G20 Anticorruption Working Group called for greater protection of whistleblowers willing to expose corruption. $^{7}$

\footnotetext{
2 A Stephan, 'How Dishonesty Killed the Cartel Offence' (2011) Criminal Law Review, Vol. 6, pp. 446-455;A Stephan, 'Disqualification Orders for Directors Involved in Cartels' (2011) Journal of European Competition Law \& Practice 2(6): 529-536.

${ }^{3}$ A Stephan, 'An Empirical Assessment of the European Leniency Notice' (2009) Journal of Competition Law \& Economics 5(3):537-561

${ }^{4}$ G Schnell, 'Bring In the Whistleblowers and Pay Them - The Next Logical Step in Advancing Antitrust Enforcement' (November 2013) CPI Antitrust Chronicle, 2.

${ }^{5}$ LM Baynes, 'Just Pucker and Blow?: An Analysis of Corporate Whistleblowers, the Duty of Care, the Duty of Loyalty, and the Sarbanes-Oxley Act' (2002) St. John's Law Review 76, 875

${ }^{6} \mathrm{~N}$ Schichor, 'Does Sarbanes-Oxley Force Whistleblowers to Sacrifice their Reputations? An Argument for Granting Whistleblowers Non-Pecuniary Damages' 8 U.C. Davis L.J 272 2007-2008 292

${ }^{7}$ G20 Anti-Corruption Action Plan, Protection of Whistleblowers: Study on Whistleblower Protection

Frameworks, Compendium of Best Practices and Guiding Principles for Legislation. (2011)
} 
This chapter considers whether the use of individual informant rewards or bounties are a viable cartel detection tool. It addresses: (1) the benefits of offering rewards to whistleblowers; (2) the design of informant rewards in South Korea and similar systems employed by other jurisdictions; (3) the question of which category of individuals these rewards should be available to; (4) the willingness of individuals to come forward and report a cartel in return for a reward; (5) how high the reward should be in monetary terms; and (6) the potential dangers of a cartel informant reward system. The chapter concludes by recommending that rewards could increase the detection rate of cartels but this is unlikely to happen unless rewards reflect the very significant cost and risk faced by individuals who are willing to come forward and inform on the actions of others within their firm or ind ustry.

\section{The Benefits of an Informant Reward Programme}

The principal gain from informants is the potential to uncover infringements that might not otherwise be revealed through leniency or through the competition authority's investigative work. This has the potential of being significantly deterrence enhancing, by increasing the rate at which cartels are discovered without any significant increase in enforcement resources. ${ }^{8}$ As the whistleblower can be a single individual, it is also less likely that their actions are part of strategic behaviour by one firm of the sort described above in relation to leniency. They may therefore be effective at uncovering cartels that are otherwise stable despite the presence of leniency. Three further deterrence enhancing effects can be identified:

Cartel Instability - An informant reward programme that creates a legitimate threat for cartels could increase deterrence by making existing infringements less stable and encouraging distrust between cartel members. ${ }^{9}$

Raising the Cost of Collusion - Rather than simply having to ensure that no party to a cartel cheats or applies for leniency, informant rewards force the cartel to compensate every individual involved in the infringement or aware of its existence. Each of these potential whistleblowers must be prevented from coming forward, either through threats or bribes, both of which are associated with a cost. ${ }^{10}$

Reducing the Cartel's Effectiveness - In order to manage the risk of whistleblowers, a cartel may choose to reduce the number of people in each firm directly involved in the cartel, or heighten measures aimed at concealing the activity. Both of these will

\footnotetext{
${ }^{8}$ WE Kovacic, 'Private Monitoring and Antitrust Enforcement: Paying Informants to Reveal Cartels' (2001) 69 George Washington Law Review 766, p774

9 P Schoff, 'Pay offs for cartel tip offs' (12 September 2013) MinterEllision Available: http://www.minterellison.com/Media/Pay-offs-for-cartel-tip-offs/

${ }^{10} \mathrm{C}$ Aubert et al, 'The Impact of Leniency and Whistle-Blowing Programs on Cartels' (2006) 24 International Journal of Industrial Organisation 1241, 1251-52
} 
have an adverse affect on the administration and efficiency of the cartel arrangement, eroding its success at achieving anti-competitive effects. ${ }^{11}$

These benefits appear to constitute a strong justification for the use of informant rewards. Policing markets for anticompetitive conduct is extremely difficult and very resource intensive. This has been the central justification for the use of leniency. Informant rewards are arguably more legitimate than leniency programmes because they benefit just one individual (as opposed to an entire undertaking), and that individual will not necessarily be a direct participant in the illegality.

The use of informants is central to the US criminal justice system. The government there 'has long maintained that certain kinds of cases would be impossible to investigate or prosecute without informants'. ${ }^{12}$ For an example of how significant informants can be, one need look no further than the most famous Antitrust informant of all, Mark Whitacre. ${ }^{13} \mathrm{His}$ experience, depicted in the 2009 film The Informant staring Matt Damon, is not typical of the kind of informant envisaged for the purposes of this study. Whitacre was embezzling money from his employer, Archer Daniels Midland, and invented a story of corporate sabotage and blackmail to cover his activities. The FBI had been called in by the firm to investigate this and Whitacre, under pressure from his wife, told them about the unrelated price-fixing practices. In the years that followed, he helped the FBI and Department of Justice conduct covert filming of the Lysine cartel. The focus of his story usually falls on his personality and bizarre behaviour, which was driven by undiagnosed mental health problems. However, it can be argued that his actions helped bring down countless related cartels in the international chemicals industry. We know, for example that the FBI were made aware of ADM's involvement in the price fixing of Citric Acid and Sodium Gluconate at the early stages of their investigation. ${ }^{14}$ Those two cartels, together with Lysine, can be linked via common membership to Vitamins, Methylglucamine, Animal Feed Methionine, Animal Feed Vitamins, Food Flavour, Organic Peroxides and MCAA Chemicals and beyond. Whitacre's cooperation contributed to the busting of at least thirteen different cartels in the industry. In terms of fines, these accounted for more than half the European Commission's cartel enforcement activity between 2000 and April 2007. ${ }^{15}$

\section{The Design of Informant Rewards in South Korea and beyond}

\footnotetext{
${ }^{11} \mathrm{R}$ Howse and R Daniels, 'Rewarding Whistleblowers: The Costs and Benefits of an Incentive-Based Compliance Strategy' in RJ Daniels and R Morck (eds) Corporate Decision-Making in Canada (Calgary: University of Calgary Press 1995) p531

${ }^{12}$ A Natapoff, Snitching: Criminal Informants and the Erosion of American Justice (New York University Press 2009) p142

${ }^{13}$ See generally: K Eichenwald, The Informant (New York: Broadway Books 2000)

14 Ibid.

${ }^{15}$ See Stephan (n 3) Figure 4.
} 
South Korea enacted its Monopoly Regulation and Fair Trade Act (MRFTA) in December 1980 as part of its efforts to liberalise markets, abolish direct price controls, and encourage trade and investment. It was also part of a package of measures aimed at curbing the power of the chaebol that dominated the Korean economy. These largely family run conglomerates were important to the industrialisation of South Korea, its rapid economic growth and its access to international markets. However, they represented damaging concentrations of economic and political power and were blamed for compounding economic crises in the early 1980s and late 1990s. ${ }^{16}$ The 1997 crisis in particular served to highlight inefficient aspects of the chaebol, their lack of transparency and the 'too big to fail' problem which contributed to the country's debt crisis. ${ }^{17}$ Early Korean competition law included large exemptions on industrial and social policy grounds. These were revoked in 1999, bringing Korean competition law broadly in line with that of the European Union and United States. ${ }^{18}$ It also became a requirement that government authorities consult with the Korean Fair Trade Commission (KFTC) before taking any legislative or administrative measure that might restrict competition. Korea adopted a leniency programme in 1997 and made significant reforms in 2005 and 2009. ${ }^{19}$ As a result, Korea is now one of the most active cartel enforcement regimes in the world, with around half of its cases relying on revealing parties. ${ }^{20}$ In 2008 alone, the KFTC imposed approximately 205 billion Won (USD \$192 million) in administrative fines with respect to 43 cartel cases. ${ }^{21}$

The KFTC first introduced a system of rewards for informants in cartel cases in February 2002. Initially these rewards could only be a maximum of 20 million Won (USD $\$ 19,000)$ and the level of reporting fell short of the KFTC's expectations. ${ }^{22}$ This was subsequently increased to a maximum of 100 million won (USD \$94,000). ${ }^{23}$ In December 2004, an amendment was made to the MRFTA introducing a formal reward mechanism for Informants. This set out where rewards would be offered and explicitly excluded situations where there was no finding of an infringement or where the evidence submitted was insufficient. The amendment also clarified that a reward would only be available to the first whistleblower. ${ }^{24}$ The size of rewards is determined by a Committee whose role it is to ensure fairness and transparency. ${ }^{25}$ As well as increasing the reward, the protection of

\footnotetext{
${ }^{16} \mathrm{~K}$ Shin, 'Competition Law and Policy' in S Haggard et al (eds), Economic Crisis and Corporate Restructuring in Korea (Cambridge University Press 2003) p266.

${ }^{17}$ See generally Lim et al, 'Introduction: The Political Economy of Corporate Restructuring' in S Haggard et al (eds), Economic Crisis and Corporate Restructuring in Korea (Cambridge University Press 2003) pp. 1-31.

${ }^{18}$ Shin (n 16) p271

${ }^{19}$ S R Koh and J Jeong, 'To Apply or Not: Leniency Program in Korea and Its Effectiveness' (2012) unpublished manuscript. Available: http://pubfin.nccu.edu.tw/event/icrecp/2-1.pdf

20 Ibid.

${ }^{21}$ Ibid.

22 Korean Fair Trade Commission, Annual Report 2003, p6

${ }^{23}$ KFTC, Guidelines for Enforcing the Leniency Program for the Informant Reporting the Improper Concerted Act.

${ }^{24}$ Korean Fair Trade Commission, Annual Report 2006 p7

${ }^{25}$ KFTC, 'KFTC's launch of Reward System for Informants' Press Release (March 2005). Available: http://www.ftc.go.kr/data/hwp/rewardsystem.doc
} 
confidentiality became guaranteed by enforcement decree. The changes made to the Korean informant reward scheme in $\mathbf{2 0 0 5}$ were a response to a lack of informants coming forward. It was thought this was due to cultural barriers, fear of retaliation and the low level of rewards available. ${ }^{26}$

By 2006, the Informant Reward Programme had been used on 8 occasions. ${ }^{27}$ Due to confidentiality, most instances of informant rewards are not publicised. A reward of 66.87 million Won (USD \$62,657) was paid in June 2005 to an individual who provided evidence in connection with a Welding Rod cartel. It is thought that the infringement might not have come to light were it not for this individual. ${ }^{28}$ The information provided included names of executives in the six cartel member companies, meeting places and details of the agreement. In 2007, a 210 million Won (USD $\$ 197,000$ ) reward was granted to an informant for information relating to a sugar cartel. Finally in 2011, the Commission awarded a 50 million Won (USD \$46,000) reward in a bid rigging case. ${ }^{29}$ In December 2012, the KFTC raised the maximum amount of award money granted to cartel whistleblowers to 3 billion Won (USD $\$ 2.8$ million). ${ }^{30}$

Individual rewards are not the only unusual characteristic of Korea's leniency arrangements. Their corporate leniency programme allows multiple firms to lodge joint applications for leniency in certain circumstances. This was to address problems that arose where companies seeking leniency were defined as separate undertakings even though they were affiliates belonging to the same business group. There were cases where the evidence required to secure leniency was dispersed between two or three such undertakings. ${ }^{31}$ Joint applications are also possible where a division engaged in cartel activity has been sold to another firm. In this situation both firms can come forward. Korea also has a criminal

\footnotetext{
${ }^{26} \mathrm{~K}$ Sullivan et al 'The Potential Impact of Adding a Whistleblower Rewards Provision to ACPERA' (October 2011) The Antitrust Source, discussing : B Kim (KFTC), 'Measures to Improve Cartel Detection (Other than Leniency)' Speech at ICN Cartel Workshop, Seoul, South Korea, 8 November 2005. Available: http://www.internationalcompetitionnetwork.org/uploads/library/doc681.pdf

${ }^{27}$ B Kim (KFTC), 'Measures to Improve Cartel Detection (Other than Leniency)' Speech at ICN Cartel Workshop, Seoul, South Korea, 8 November 2005. Available: http://www.internationalcompetitionnetwork.org/uploads/library/doc681.pdf

${ }^{28}$ KFTC, 'A Reward of 66.87 million won Paid to Informant of Welding Rod Cartel' (2005) Press Release. Available: http://www.ftc.go.kr/data/hwp/rewardsystem.doc

${ }^{29}$ Freshfields Bruckhaus Deringer, Reaching further, getting tougher: Lessons from Asia's fast-evolving competition laws. (October 2013). Available: http://www.freshfields.com/uploadedFiles/SiteWide/Knowledge/ACT\%20Asia\%20\%20Reaching\%20further\%20getting\%20tougher\%20-\%200ctober\%202013.pdf

30 'Reward for Reporting Cartel Conduct Increased to KRW 3 Billion' (January 2009), OECD Asia-Pacific Competition Update, Issue 8; JS Kim (Director, Cartel Policy Division, KFTC), 'Cartel Regulation in Korea' (2012). Presentation at Asian Development Bank Institute. Available: http://www.adbi.org/files/2012.05.02.cpp.sess3.3.kim.cartel.regulation.korea.pdf ${ }^{31}$ P S Rhee and S S Yun, 'South Korea: Tackling Cartels' (1 October 2009) IFLR. Available: http://www.iflr.com/Article/2324375/South-Korea-Tackling-cartels.html
} 
offence which can carry fines of up to 200 million Korean Won and/or a prison sentence of up to three years. The Prosecutor's Office pursues such cases upon referral from the KFTC. ${ }^{32}$

Informant reward mechanisms have also been adopted in the United Kingdom, Hungary and Pakistan. In addition, such mechanisms exist in other areas of law enforcement within the United States.

\section{United Kingdom}

In 2008, the UK's Office of Fair Trading (OFT) ${ }^{33}$ began offering up to $£ 100,000$ (USD $\$ 165,780)$ for the provision of information on cartel activity. ${ }^{34}$ The reward is available only in 'exceptional circumstances'. . The OFT's justification for the reward was that, 'Cartels are generally conducted in secret and they can be hard to detect and prove', and therefore,

'the OFT believes it should offer financial rewards for information which helps in the detection and investigation of cartels and which, in appropriate cases, leads to the fining of the companies and the criminal prosecution of individuals involved'. ${ }^{35}$

The OFT advises prospective whistleblowers to approach them before obtaining further information or evidence on the cartel. This is so that they can discuss in advance the risks that might be involved in disclosing the information and whether the whistleblower should proceed. ${ }^{36}$ They promise to 'very carefully safeguard any information [given] to protect [the whistleblower's] identity from disclosure'.

The granting of rewards is entirely at the OFT's discretion. Even if they agree to 'accept some information from a person and the information provides a credible basis for further investigation' the OFT is still free to decide that, 'on the basis of other more pressing priorities, that it will not use the information given and will not therefore give a financial reward'. The reward could be substantially less than $£ 100,000$ and there is no upfront guarantee as to the final amount.

Where the whistleblower has been directly involved in the cartel, they are eligible for immunity if they are the first to report the infringement. On the question of whether that individual can also gain from a financial reward, the OFT states,

'...there may be circumstances where the OFT will consider a reward in addition to immunity from sanction under the leniency policy. This is most likely to be

\footnotetext{
${ }^{32}$ T Banks and N Jalabert-Doury, Competition Law Compliance Programs and Government Support or Indifference' (2012) Concurrences No2-2012

${ }^{33}$ From April 2014 the OFT will be merged with the UK's Competition Commission to form the Competition and Markets Authority (CMA)

${ }^{34}$ http://www.oft.gov.uk/OFTwork/competition-act-and-cartels/cartels/rewards

35 Ibid.

${ }^{36}$ Ibid.
} 
considered where the role of the person in the cartel was relatively peripheral - for example that of an employee who was occasionally directed by his superiors to attend a cartel meeting and who was not asked to take an active part in decisionmaking about the cartel'

\section{Hungary}

The Hungarian Competition Authority (Gazdasági Versenyhivatal - GVH) introduced a 'Cartel Informant Reward' system in April 2010. ${ }^{37}$ It applies to individuals who provide 'indispensible' information. Its justification is that,

'informants who disclose the existence of a cartel... take financial risk because of the cartelists' possible revenge; this risk has to be counterbalanced in order to maintain their motivation to assist in the enforcement of the law'.

Rewards are only provided in return for 'written evidence qualifying as indispensable'. ${ }^{38}$ It appears that even individuals directly involved in cartels can benefit from a reward. The reward can be a maximum of 50 million HUF (USD $\$ 224,000$ ) and there are guarantees of anonymity.

\section{Pakistan}

The Competition Commission of Pakistan introduced a 'Reward Payment to Informants Scheme' with the aim of uncovering cartel activity. It involves a payment of between Pak Rs $2-500,000$ (USD $\$ 1,900$ - $\$ 4,700$ ). The payment of the reward is conditional on the information provided being accurate, verifiable and useful to the authority's cartel enforcement work. Informants are given a token payment in return for their cooperation within 30 days of the authority receiving the information. Full payment is made within six months. ${ }^{39}$

\section{United States}

While the US has rejected the use of informant rewards in antitrust cases (discussed later in this chapter), proponents have cited the use of such mechanisms in other areas of US law

\footnotetext{
${ }^{37}$ Hungarian Competition Authority, 'Regular Questions about the Cartel Informant Reward' Press Rel ease.

${ }^{38}$ Categories of eligible documents are set out in Act CXL of 2004 on the General Rules of Public Administrative Procedures and Services.

${ }^{39}$ Competition Commission of Pakistan, Revised Guidelines on "Reward Payment to Informants Scheme" Available: http://www.cc.gov.pk/images/Downloads/guidlines/reward paymentannexure ii.pdf; See alsol Ahmed, 'Leniency and Reward Payments in Pakistan' speech at OECD Workshop on Rewarding Cooperation in Cartel Investigations, OECD Korea Policy Centre. 14-16 March 2012
} 
enforcement. In particular, under the US False Claims Act a person who becomes aware of fraud against government may take action on the government's behalf and is entitled to a percentage of damages if the case is successful. Under this so called qui tam system, where an individual informs the Department of Justice and they successfully prosecute the alleged misconduct, the whistleblower receives 25 per cent of the money recovered by the government. If the government decides not to proceed or is unsuccessful, the whistleblower can still proceed with their own action and will keep 30 per cent of any funds recovered. Under this mechanism, the US government succeeded in recovering \$3.5 billion between 1986 and $2000 .^{40}$ In 2001, the qui tam mechanism was used to expose a cartel involving the bid rigging of USAID funded water treatment projects in Egypt. ${ }^{41}$

Similarly, the Dodd-Frank Wall Street Reform and Consumer Protection Act allows whistleblowers to lay claim to financial bounties for providing information to the Securities and Exchange Commission, that leads to successful securities enforcement actions. The Act allows an individual who provides information which leads to a successful SEC enforcement to receive a minimum of 10 per cent and a maximum of 30 per cent of monetary sanctions over \$1 million. This is limited to rare SEC actions where a seven figure enforcement sanction is imposed and so for the vast majority of whistleblowers, a bounty will not be available. $^{42}$

Following the financial crisis of 2007-8 other juris dictions have considered an increased role for informant rewards in the context of financial market conduct. In 2011, the European Commission proposed a Regulation on Market abuse with the proposed inclusion of rewards for whistleblowers. ${ }^{43}$

\section{Who should Cartel Informant Rewards Be Available To?}

Informant rewards could potentially motivate a number of different whistleblower groups to report cartel infringements. These include:

1. Individuals directly involved in the infringement

2. Individuals employed by cartel firms but working at the periphery of the infringement

3. Other employees of the firm who are aware of the infringement

4. Disgruntled employees or those recently dismissed

\footnotetext{
${ }^{40} \mathrm{M}$ Bloom, 'Despite Its Great Success, the EC Leniency Program Faces Great Challenges' (2006) European University Institute Working Paper EUI-RSCAS

41 Ibid.

${ }^{42}$ GC Rapp, 'Mutiny by the Bounties? The Attempt to Reform Wall Street by the New Whistleblower Provisions of the Dodd-Frank Act' (2012) Brigham Young University Law Review 73

43 Proposal for a Regulation of the European Parliament and of the Council on insider dealing and market manipulation (market abuse) $\operatorname{COM}(2011) 651$, at 3.4.5.2
} 
5. Individuals who have a social interaction with those involved

Some academic studies on whistleblowing include buyers and other groups in this category. ${ }^{44}$ However, external actors may not have access to key pieces of information that are necessary in order for the competition authority to effectively pursue the alleged cartel conduct. As we have seen in Section 3, competition authorities retain full discretion on whether a reward is justified and so there needs to be more than simply a vague tip-off as to the industry and alleged members. One of the most fruitful categories of whistleblower may be the disgruntled former employee who, in a desire for revenge, has kept information relating to their former employer's corporate misbehaviour. This category of whistleblower does not face the same risks or costs as current employees. In an Antitrust example of this, a Vice-President of General Electric once reacted to his dismissal by lodging charges of pricefixing against the company. ${ }^{45}$ Gobert and Punch pose the question of why he waited until he had left the firm, suggesting that he was prepared to go along with corporate misbehaviour for as long as it benefited him.

One key consideration is whether informant rewards should be made available to individuals directly involved in the cartel arrangement. There is an issue of legitimacy here, in that these individuals would not simply gain from leniency or a reduced sanction, but would actually receive a monetary reward funded by the tax payer (albeit off-set by any fines subsequently recovered). Schnell suggests that rewards to individuals not involved in the cartel could actually boost legitimacy because they potentially by-passe the need to reward guilty parties with immunity and leniency in order for the infringement to be revealed. ${ }^{46}$ However, those directly involved may be the only individuals with access to sufficient information for a credible approach to the competition authority. Cartel organisation varies widely between infringements and it is unclear how reasonable it would be to expect employees not directly involved in the infringement to have access to sufficient information to act as whistleblowers.

We know that cartel infringements are not generally administered within the institutional framework of the firm. Indeed, cartels appear to be characterised by clandestine actions designed to ensure the collusive arrangements are hidden from both the authorities and the wider undertaking. ${ }^{47}$ Infringements uncovered over the last decade demonstrate the lengths cartels will go in order to keep their arrangements secret. Efforts to conceal cartels have included: communicating through private email accounts and unregistered mobile phones; using encrypted messages and codenames; avoiding contact through secretaries or the

\footnotetext{
44 J Harrington, 'Optimal Deterrence of Competition Law Infringements' Presentation at Conference, Deterring EU Competition Law Infringements: Are we Using the Right Sanctions, Brussels, 3 December 2012.

$45 \mathrm{~J}$ Gobert and M Punch, 'Whistleblowers, the Public Interest, and the Public Interest Disclosure Act 1998' (2000) 63 Mordern Law Review pp 25-54 p31; 'Diamonds and Dirt: A Fired Executive's Price-Fixing Charges Dog GE' (10 August 1992) Business Week

${ }^{46}$ Schnell (n 4) p2-3

${ }^{47}$ A Stephan 'See no Evil: Cartels and the Limits of Antitrust Compliance Programs' (2010) The Company Lawyer 31(8), 231-239
} 
involvement of any administrative staff; and hiding expenses relating to cartel meetings as other legitimate costs. ${ }^{48}$ Moreover, cartel meetings tend to occur in hotel rooms, private conference rooms and restaurants.

Given the level of secrecy involved, it may be unwise to exclude individuals directly involved in the collusion from an informant reward scheme. It is also notable that theoretical economics papers, such as Buccirossi and Spagnolo, find that reward schemes for cartelist whistleblowers have the effect of reducing the minimum fine that is likely to have some deterrent effect. ${ }^{49}$ They estimate this drops to below 10 per cent of the optimal fine under the Beckarian economic paradigm of deterrence. However, these papers usually assume very substantial levels of informant reward.

There are thus good reasons to include cartelists as an eligible group for informant rewards, but some protection is needed to avoid the moral hazard problem of individuals instigating offences in order to secure a reward. Although this scenario may be unlikely, it is nevertheless important that informant rewards not made available to individuals found to have been involved in setting up a cartel.

\section{Willingness to Report a Cartel in Return for a Reward}

The act of whistleblowing can carry with it enormous personal risks for the informant. The first obstacles they must overcome are institutional constraints and their sense of loyalty to the employer. Corporate structures are generally designed to ensure employees behave in the firm's interest and that they do not disclose confidential or classified information to outsiders. Even where formal rules do not exist, employees will generally understand that 'dirty linen is not to be washed in public'. ${ }^{50}$

As Gobert and Punch point out, investigative journalism reveals countless examples of where corporate misbehaviour (and that of public authorities) is hidden by employees who assist in cover ups and manipulation. ${ }^{51}$ Far from being the natural course of action, whistleblowing may be going against the grain of business and government organisations, which 'tend to be characterised as defensive, secretive and self-serving bureaucracies' ${ }^{52}$ Some even argue that whistleblower 'protection' laws are deliberately crafted so that whistleblowing is costly to the ordinary citizen thinking of revealing wrongdoing. This is

\footnotetext{
48 Ibid p6.

49 P Buccirossiand G Spagnolo, 'Optimal Fines in the Era of Whistleblowers. Should Price Fixers Still Go to Prison?' (2005) Lear Res earch Paper 05-01

50 Ibid.p28

${ }^{51}$ Gobert and Punch (n 45) p26

52 Ibid.
} 
because by definition whistleblowing can threaten those in power. ${ }^{53}$ For example, in Hungary it has been alleged that public bodies and businesses have colluded to suppress whistleblowers alleging corporate misbehaviour. ${ }^{54}$

In the US, high profile informants have usually cooperated under the duress of their own pending criminal prosecutions. Natapoff notes,

'[The US] government's financial fraud cases against Enron's chief officers Kenneth Lay and Jeffrey Skilling were built on the testimony of numerous informants, including accountants and managers as well as CFO Andrew Fastow. Many of these witnesses were also guilty but received reduced sentences in exchange for their cooperation $^{55}$

Arguably without the existence of criminal offences and a justice system flexible enough to reward cooperation with significant reductions in penalties, the incentive to cooperate is weak. When considering the introduction of informant rewards, the US Department of Justice hinted that the threat of criminal enforcement already creates sufficient incentive for insider cooperation. ${ }^{56}$ However, not every competition law jurisdiction has a criminal offence against individuals involved in cartels that they can use as leverage. Indeed, the level of criminal antitrust enforcement outside the US is very low and most legal cultures do not allow the level of prosecutorial discretion and plea bargaining that characterises the US justice system. Absent the threat of criminal prosecution and the availability of plea bargains, employees' natural tendency might be to align their interests with those of the employer. Keen to dissuade employees from whistleblowing, firms may pay their employees' legal costs and possibly even compensate them.

It has been suggested that cultures of whistleblowing are more easily encouraged in individualistic Anglo-Saxon cultures, in contrast to more collectivist cultures where there is a strong stigma associated with the act of 'snitching'. ${ }^{57}$ While there may be some merit in this argument, the experience of Korea and Japan suggests this effect may have been overstated. Apart from the number of informant cases in Korea, both Japan and Korea have very successful leniency programmes, despite predictions that neither corporate culture would be compatible with leniency.

Normative perceptions are also important. Miceli et al conducted a survey of internal auditors to gauge factors that affected their propensity to report wrongdoing by employees

\footnotetext{
53 MK Ramirez, 'Blowing the Whistle on Whistleblower Protection: A Tale of Reform Versus Power' (2008) University of Cincinnati Law Review 76 pp 183-234

54 E.g. 'Hungary tax whistleblower: People who expose corruption have to be afraid' Euronews 29 December 2013.

${ }^{55}$ Natapoff (n 12) p155

${ }^{56}$ Natapoff (n 12) p45

${ }^{57}$ C Rimoldi, 'Whistl eblowing at Work: Ethical and Judi cial Issues' (2007) unpublished paper. UNIVERSITÀ CARLO CATTANEO - LIUC; A Stephan, 'Cartel Laws Undermined: Corruption, Social Norms and Collectivist Business Cultures' (June 2010) Journal of Law and Society 37(2) pp. 345-67
} 
and managers. Their study found that reporting was less likely when they did not feel compelled morally. ${ }^{58}$ So if, for example, they envisage that their family and friends may suffer as a result of the behaviour, they would be more likely to report. ${ }^{59}$ Unfortunately, in contrast to misconduct involving violence or fraud, it is unclear whether ordinary citizens have a strong sense that price fixing is wrong or that it should be punished. A public survey carried out by this author in the UK in 2007, found that while most members of the public understood that price fixing was harmful, support for severe sanctions was relatively weak. ${ }^{60}$ The problem is further compounded by the fact the harm caused by price fixing is dispersed and hard to quantify, and by the fact it directly benefits the firm. So for example, an employee might be more willing to report a fellow employee who is stealing from the business or operating in a manner that serves their personal interests over those of the company. There have even been cases where whistleblowing of this sort of behaviour has actually resulted in a reward from the employer in the form of an ex gratia payment ${ }^{61}$ Price fixing usually benefits both the undertaking and the individual.

It is important to acknowledge that whistleblowing forces employees into a situation where their cooperation is in direct conflict with their duties to the firm. In providing the authority with confidential information about a breach of the law, they put themselves in danger of being dismissed and/or sued for breach of confidence in the event that their identity is discovered. In the absence of a positive statutory duty to come forward, this breach of confidence is not necessarily trumped by the offer of an informant reward.

Stanley Adams was an employee of Hoffman La Roche. He discovered significant anticompetitive practices within the organisation and decided to report this to the European Commission in 1973. He began his letter to the Commission with,

'I am writing this letter out of a sense of duty, and I trust that you will be able to take some action in the matter. I am not after any position in the EEC institutions, nor am $\mathrm{I}$ in any way interested in compensation of any kind'. ${ }^{62}$

The letter was signed off with, 'I request you not to let my name be connected with this matter. However, I remain at your entire disposal for further information as well as documentary evidence about every point which I have raised in this letter'.

The information he provided launched an investigation and a fine was subsequently imposed on the firm. The Commission failed to adequately protect Adams' identity,

\footnotetext{
${ }^{58}$ MP Miceli, JP Near and CR Schwenk, 'Who Blows the Whistleand Why?' (1991) Industrial and Labor Relations Review, Vol. 45, No. 1 pp 113-130

${ }^{59}$ E.g. JB Dozier and MP Miceli, 'Potential Predictors of Whistle-Blowing: A Prosocial Behaviour Perspective' (1985) Academic Management Review, 10, 823

${ }^{60}$ A Stephan 'Survey of Public Attitudes to Price-Fixing and Cartel Enforcement in Britain' [2008] 5(1) Comp. Law Review pp123-145

${ }^{61}$ Gobert and Punch (n 45) p28

${ }^{62}$ Eric Newbigging, 'Hoffman-La Roche v Stanley Adams - Corporate and Individual Ethics' (1986) Cranfield University Working Paper. Available: https://dspace.lib.cranfield.ac.uk/handle/1826/471 p6
} 
disclosing his name and address in documents provided to La Roche. As a result, he was prosecuted under Swiss laws that made it an offence to pass on confidential business information to a foreigner. ${ }^{63} \mathrm{He}$ became bankrupt and his wife reportedly committed suicide upon hearing that he would receive a twenty year prison sentence. ${ }^{64}$ In November 1985 he successfully sued the Commission for negligence and breach of confidence over his disclosures. In reflecting over his experience, Adams stated,

'I had not been brought up under the Swiss System with the belief that corporate loyalty is inviolable at all times, and what the Company must be good, because your welfare is dependent on the company's welfare, and the company's welfare is dependent on the welfare of all companies put together, and the chain may not and cannot be broken without grave consequences to all concerned. ... I had been brought up to question the status quo, not to take things for granted, to explore other ways of doing things. It was second nature to me to ask why something was done this way, and not that way. Ironically, it was just this quality that helped me advance in Roche. Applied to every day problems, it was creative and useful. Applied to the ethics of business, it was embarrassing and challenging and had to be suppressed immediately.' ${ }^{65}$

Adams' tragic fate was sealed by the European Commission's failure to protect his identity, coupled with a lack of protection from retaliatory measures. It demonstrates the dire consequences some whistleblowers can face as a result of coming forward.

The US Senate passed a bill in November 2013, aimed at preventing retaliation against whistleblowers who report criminal antitrust violations. It states that,

'No employer may discharge, demote, suspend, threaten, harass, or in any other manner discriminate against a covered individual in the terms and conditions of employment of the covered individuals'

The Criminal Antitrust Anti-Retaliation Act 2013 amends the Antitrust Criminal Penalty Enforcement and Reform Act of 2004 by adding civil whistleblower protections for individuals who assist an investigation or a proceeding relating to criminal antitrust offences. ${ }^{66}$ The information provided must relate to an act the individual reasonably believes to be a violation of antitrust laws (or of other crimes in conjunction with antitrust law). The bill excludes protection from anyone who has planned or been involved in a violation of antitrust laws or who has attempted to obstruct the Department of Justice. ${ }^{67}$

\footnotetext{
63 Ibid.

64 Ibid. p11.

${ }^{65}$ Ibid. p5-6

${ }^{66} \mathrm{M}$ Dixon and D E Shulak, 'Senate passes bill adding whistleblower protection in antitrust cartel investigations' (21 November 2013) Hogan Lovells. Available: http://www.lexology.com/library/detail.aspx?g=32d070b105ca-425b-a4cd-e4c438f8f795

${ }^{67}$ Criminal Antitrust Anti-Retaliation Act of 2013, S 42 133th Cong (2013) at 3-4
} 
'Covered individuals' are defined as employees, contractors or agents of the employer. ${ }^{68}$ At time of writing the Bill has bipartisan support and is very likely to become law. ${ }^{69}$ The provisions are not dissimilar to the Sarbanes-Oxley $\mathrm{Act}^{70}$, which was adopted following major corporate and accounting scandals such as ENRON, which resulted in billions of dollars in losses for investors and undermined confidence in US securities markets. Similar protection is provided in the UK by the Public Interest Disclosure Act 1998. It shields whistleblowers from detrimental treatment by their employer, protecting any disclosure of information associated with a reasonable belief that a criminal offence has been committed or will be committed, among other 'qualifying disclosures' (s 43B), from retribution from their employers. Notably, this type of legislation does not prevent employers from suing an informant for breach of confidence or breach of fiduciary duty. While such actions appear to be very rare, but they nevertheless pose a disincentive to whistleblowing.

While whistleblower protections are well intended, they do not go far enough in protecting whistleblowers from retaliatory measures, nor do they do anything to create an incentive to come forward in the first place (discussed below). ${ }^{71}$ In relation to the Sarbanes-Oxley, for example, there is little evidence that the act has succeeded in affording adequate protection to whistleblowers, with very few complaints settled in favour of employees and the watering down of the Act by the SEC in granting wide exemptions to foreign firms operating in the US. ${ }^{72}$ In the context of the UK's Public Interest Disclosure Act, there are no provisions to prevent firms from creating de facto blacklists of whistleblowers or to protect them from libel suits in the event that the allegations are untrue. Protections in other parts of the EU are even weaker, principally because of data protection laws. For example, the French Data Protection Authority has in the past refused to allow the setting up of anonymous whistleblower hotlines because of the risks of 'slanderous denunciations'. ${ }^{73}$

\section{How High Does the Reward Need to Be?}

The biggest obstacle to the effective use of informant rewards in cartel cases may be the size of bounty necessary to outweigh the very significant risks and costs faced by whistleblowers. ${ }^{74} \mathrm{~A}$ study of corporate whistleblowers examined whether incentives to

\footnotetext{
68 Ibid.

69 J Burns, 'United States: Senate Passes An Antitrust “Whistleblower” Protection Bill' (8 January 2014) Dickson Wright. Available: http://www.mondaq.com/unitedstates/x/284812/Antitrust+Competition/Senate+Passes+An+Antitrust+Whistl eblower+Protection+Bill

${ }^{70}$ Sarbanes-Oxley Act of 2002, 15 U.S.C. § 7201 et seq., PL 107-204, 116 Stat 745 (2002)

${ }^{71}$ Schnell (n 4) p3.

72 S May, G Cheney, and J Roper, The Debate over Corporate Social Responsibility (Oxford University Press 2007) p430

73 'Whistleblowers: Tales from the back office' (23 March 2006) The Economist.

74 D Low and D Kotchen, 'Rewards Would Help Leniency Plan, Cartel Reporting' (23 June 2009) Law360. Available: http://www.law360.com/articles/105845/rewards-would-help-leniency-plan-cartel-reporting
} 
report (absent any reward) are adequate, by asking whether existing whistleblowers would blow the whistle again. It concluded that most would choose not to. ${ }^{75}$ According to Alford,

'the average whistleblower of my experience is a 55 year old nuclear engineer working behind the counter at Radio Shack [a US electronics retailer]. Divorced and in debt to his lawyers, he lives in a two-room rented apartment'. ${ }^{76}$

The ADM informant, Mark Whitacre, has frequently spoken of his regret at having acted as a whistleblower, despite having received a reduced sentence for his embezzlement charges in return for his cooperation.

Five main categories of whistleblower risks or costs can identified:

Risk of Dismissal - The previous sections noted concerns about the lack of protection for whistleblowers who are subject to retaliatory action by their employer. This has been found to be the most significant reason why employees decline to whistleblow corporate misbehaviour. ${ }^{77}$ It is estimated that between half and two thirds of whistleblowers in the US lose their jobs. ${ }^{78}$ Even if protections exist, the whistleblower will have to undertake the significant risk and cost of challenging the employer in court or in an employment tribunal. If they are unable to show the dismissal was due to their informant activities, they could be saddled with significant legal costs.

Risk of Career End - A further problem relates to whistleblowers' ability to seek reemployment following dismissal. The same US study found that most whistleblowers effectively become blacklisted from finding re-employment within their profession. ${ }^{79} \mathrm{Glazer}$ and Migdal looked at what happened to 41 corporate informants who were dismissed or left following their whistleblowing. Two thirds had difficulty finding employment and of those, two thirds had to settle for employment in 'fields unrelated to their previous work'. ${ }^{80}$ This is what occurred in the case of Ad Bos, a Dutch engineer who blew the whistle on the Dutch Construction cartel and thereafter could not find work in the industry. ${ }^{81}$

Risk of Bankruptcy - We have seen that all four of the jurisdictions currently offering informant rewards take a cautious approach to actually paying out the bounty. Even if the informant has provided information that leads to a successful cartel case, there will be a significant time delay between the disclosure and when the authority feels comfortable enough to award the bounty. There is also an inherent lack of certainty, in that the authority retains full discretion and may disagree with the individual as to the merits of the

\footnotetext{
${ }^{75}$ Schichor (n 6)

${ }^{76}$ C F Alford, Whistleblowers: Broken Lives and Organizational Power 54 (Columbia University Press 2002). P54

${ }^{77}$ RA Johnson, Whistleblowing: When It Works - And Why (Lynne Rienner Publishers 2002) p93

${ }^{78}$ Alford (n 76) p 18

${ }^{79}$ Alford (n 76) p 18

80 JB Dozier and MP Miceli, 'Potential Predictors of Whistle-Blowing: A Prosocial Behaviour Perspective' (1985) Academic Management Review, 10, at 210, discussed in Howse and Daniels (n 11) p533.

${ }^{81} \mathrm{His}$ story was documented in the Dutch tel evision programme, Fiddling With Millions (VARA 2001)
} 
information provided. We have already established the potentially devastating consequences of not affording whistleblowers' identities sufficient protection. Nevertheless the whistleblower may find themselves in a situation where their employer discovers their actions early on in the informant process. Dismissal before the payment of any reward will put employees at risk of losing their homes (many in fact do lose their homes ${ }^{82}$ ) and may put enormous pressure on their families. They may also have to find money to protect themselves from legal action by the employer - especially if they have disclosed confidential documents.

Employers have in the past taken legal action to stop whistleblowers disclosing documents and have even pursued a strategy, known as 'nuts and sluts' of casting doubt on the character and even the sanity of the individual. ${ }^{83}$ When a company lawyer in a US gas firm alleged the Chief Executive had ordered him to submit fraudulent stock options to the Securities and Exchange Commission, the employer successfully sued him. As well as recovering documents that might have proven the allegation, they secured an injunction preventing the individual from making the allegations again and even convinced the court to recommend that he undertake psychiatric treatment. ${ }^{84}$

Social pressures - It is not uncommon for there to be an overlap between an employee's work and social life. In many parts of the United States and Canada, for example, there is only one major employer in a given town. It is therefore inevitable that one's friends are also employees of that firm. When these social groups learn of an individual's whistleblowing activity, their reaction is more likely to be one of betrayal and fear of harm to their employer, than any sense of admiration for doing the right thing. Therefore as well as risking losing their job, career and financial stability, the act of whistleblowing could also lead to an individual being ostracised from their social groups. The sense of betrayal can even spill over into threats of violence and death. Examples of this include Jeffrey Wigand (the famous tobacco industry informant in the 1990s) and Jack Palmer (who revealed alleged visa fraud). ${ }^{85}$

Family and personal pressures - The cumulative effect of the factors outlined above put enormous pressure on the whistleblower's family and personal wellbeing. It is unsurprising that a high proportion of corporate informants are reported to suffer from family breakdowns and alcohol abuse. ${ }^{86}$ The act of whistleblowing can literally destroy lives.

So how high must a reward be in order to counter the dangers outlined above? As Kovacic suggests, 'a bounty arguably must be large enough to compensate the employee for

\footnotetext{
${ }^{82}$ Alford (n 76); Schichor (n 6) p294

83 'Whistleblowers: Tales from the back office' (23 March 2006) The Economist.

84 Ibid.

${ }^{85}$ Whistle-Blower Claiming Visa Fraud Keeps His Job, but Not His Work' (12 April 2012) The New York Times

Avaialble: http://www.nytimes.com/2012/04/13/us/whistle-blower-claiming-visa-fraud-keeps-his-job-but-nothis-work.html? $r=2 \&$

${ }^{86}$ Alford (n 76); Schichor (n 6) p294
} 
liquidating her career and accepting the costs of social stigma that might result from informing ${ }^{\prime}{ }^{87}$ If we assume a whistleblower earns $\$ 80,000$ a year and is 40 years old, the reward will need to be at least $\$ 2$ million to compensate for prospective loss of income (assuming he would work until the age of 65). That figure would probably need to be at least doubled to account for lost promotions, inflation and the loss of a pension. So a reward of \$4-5 million may be necessary just to compensate the whistleblower for the risks to his job and career. This figure does not allow for possible expensive legal defences or the risk of social, family and personal pressures. Nor does it compensate for the risk that the authority will not actually pay out a reward. This is a particular problem where the whistleblower gives information that leads to an investigation but does not result in an infringement decision. In the jurisdictions discussed above, whistleblowers are likely to get nothing in this situation, while still being exposed to the resulting risks. Paying out rewards regardless of whether an infringement is actually found would be hard to justify and raise serious concerns about abuse. Nevertheless, certainty is as important to effective whistleblowing as it is to effective leniency programmes and so a greater level of assurance is required.

Even if we make significantly more conservative estimates about the level of bounty needed, the rewards available in the UK, Hungary and Pakistan appear to fall well short of those necessary to incentivise whistleblowing. Although Korea has significantly increased the maximum reward available, the levels actually paid out (that we know about) are still relatively small.

Mechanisms that pay informants a proportion of fines or moneys recovered, such those in the US, may make it easier for rewards to reach the kind of levels necessary. For example, in 2012 a UBS banker was paid \$104 million for exposing clients' illegal offshore bank accounts to the US Inland Revenue. In 2004, Jim Alderson helped the government recover $\$ 1.7$ billion in Medicare fraud. As a consequence, he kept tens of millions of dollars. ${ }^{88}$ It is thought that by 2004 the US False Claims Act had succeeded in recovering \$12 billion for the US Treasury and more than $\$ 1$ billion for whistle-blowers. ${ }^{89}$ Thus very significant rewards are not without precedence. However, a 2011 US Government Accountability Office report dismissed the proposed use of qui tam proceedings in antitrust cases after the DOJ and a number of stakeholders said these would not be compatible with the criminal nature of antitrust violations. The DOJ has the sole authority to prosecute federal criminal cases and so a right of action in a criminal context would conflict with this authority. ${ }^{90}$ Such systems are easier to implement in a civil enforcement context.

\footnotetext{
${ }^{87}$ Kovacic (n 8) p772

88 'For Some Whistle-Blowers, Big Risk Pays Off' (29 November 2004) New York Times 89 Ibid.

90 US Government Accountability Office, 'Criminal Cartel Enforcement: Stakeholder Views on Impact of 2004 Antitrust Reform are Mixed, but Support Whistleblower Protection' (July 2011) Report to Congressional Committees GAO-11-619 at p38
} 


\section{Potential Dangers of a Cartel Informant Reward System}

An effective informant reward system is dependent on there being a sufficient incentive to come forward, coupled with trust that the authority will deal with informants fairly and will make every effort to protect their identity. In the US, where informant systems permeate every aspect of the criminal justice system, there have been cases of trust being undermined as the result of an authority promising a deal only to later back out. In one case, the informant's lawyer resorted to taking out an advert addressed to the prosecutor's office in which he wrote,

'Your office cannot be trusted. Your office cares nothing about promises and agreements. I am surprised that the eagle in the Great Seal of the United States did not fly from the wall in horror. ...Like some sleazy insurance company who refuses to pay the widow because it wants the premiums but doesn't want to honor his obligations, your office will go to any length to renege on its solemn promises. ${ }^{91}$

Beyond the way in which the authority administers an informant reward scheme, the main dangers lie in possible adverse effects on the wider enforcement system. The United States recently gave cartel informant rewards serious consideration and decided to reject them. In July 2011, The US Government Accountability Office (GAO) published a report on the effects of the Antitrust Criminal Penalty Enhancement and Reform Act. ${ }^{92}$ It had found evidence of retaliation by employers against individuals who reported criminal antitrust violations and recommended protections against retaliation implemented under the Criminal Antitrust Anti-Retaliation Act 2013. The GAO consulted with 21 key stakeholders, including defence attorneys, plaintiff's attorneys, representatives of the ABA Section of Antitrust Law, and Economics and Law academics. They found wide support for anti-retaliatory protection for whistleblowers, but only 9 stated that a whistleblower reward or bounty would result in greater cartel detection and deterrence. 11 of the 21 said such rewards would hinder the Department of Justice enforcement regime. The GAO report and academic literature on reward schemes identify a number of dangers.

Jeopardising witness credibility - One of the principal concerns expressed by the US Department of Justice in the GAO consultation, was that rewards would undermine the credibility of witnesses in antitrust trials. ${ }^{93}$ This would potentially have far reaching effects because existing (otherwise unpaid) witnesses might also demand a reward, undermining their credibility too. ${ }^{94}$ The Antitrust Division's Deputy Assistant Attorney General for Criminal Enforcement stated that 'jurors may not believe a witness who stands to benefit financially from successful enforcement action against those he implicated'. This is a

\footnotetext{
${ }^{91}$ Daniel Richman, 'Cooperating Clients' (1995) 56 Ohio St. L. J. 69 at 109

${ }^{92}$ US Government Accountability Office (n90) at 38

93 Ibid.

${ }^{94}$ Ibidp39
} 
particular problem in criminal antitrust enforcement regimes where the competition authority must convince a jury that the defendant has committed an offence. Given that some 90 per cent of US antitrust cases are settled at plea bargain, in lieu of trial, one might question whether this concern is really valid. Once a cartel is being investigated, undertakings in most jurisdictions show a very high propensity to cooperate in return for reductions in fines. Any whistleblower testimony in court may therefore be accompanied by other sources of evidence. In civil cartel enforcement regimes witness credibility is less of an issue (in terms of successful enforcement) because there is no independent adjudication of the case before appeals.

Risk of Abuse - Another prominent concern of the Department of Justice, identified in the GAO report, was the possible increase in non-credible and fraudulent claims. ${ }^{95}$ Attempts are generally made to corroborate information provided by whistleblowers under the US False Claims Act, but this is harder to do in cartel cases because a second individual is unlikely to be forthcoming. ${ }^{96}$ The secretive nature of cartels could mean an investigation is being initiated on the basis of exaggerated or fraudulent evidence. This had occurred in at least one case involving a qui tam reward. ${ }^{97}$ Others have argued that this danger has been grossly exaggerated and there is very little evidence of frivolous reporting in the existing whistleblower provisions that exist in the US. ${ }^{98}$ Claims that have been entirely fabricated should be easily identifiable by the competition authority. The incentive for firms to cooperate in return for leniency once they are under investigation, should provide the authority with additional information that will either corroborate or raise doubts as to the credibility of the whistleblower's evidence. As it is, competition authorities receive a high volume of complaints from consumers and firms and so the challenge of distinguishing genuine allegations of wrongdoing from false or frivolous ones already exists.

The availability of informant rewards to individuals directly involved in cartels creates an obvious moral hazard problem, especially if the rewards of coming forward are significant. As already discussed in this chapter, there would have to be an exclusion for individuals who instigated or were involved in setting up the cartel arrangement. This is to avoid individuals deliberately breaking the law in order to gain from the reward.

Undermining internal compliance programmes - It has been argued that internal competition law compliance programmes are crucial to creating a positive competition culture within the business community. ${ }^{99}$ They help undertakings prevent infringements by

\footnotetext{
95 US Government Accountability Office (n 90) p38

96 Ibid p40

97 Ibid p41

98 Schnell (n 4) p4

99 Stephan (n 47); J Murphy and D Boehme, 'Fear No Evil: A Compliance and Ethics Professionals' Response to Dr. Stephan' (2011) Availableat:

http://papers.ssrn.com/sol3/papers.cfm?abstract $i d=1965733 \&$ rec $=1 \&$ srcabs $=1432340 \&$ alg $=1 \&$ pos $=1$; $D$ Geradin, 'Antitrust Compliance Programmes and Optimal Antitrust Enforcement: a Reply to Wouter Wils' (2013) Journal of Antitrust Enforcement. 1(2) pp. 325-346
} 
their employees and limit their exposure to antitrust fines, by allowing them to detect potential anti-competitive practices at an earlier stage. Many of these include confidential informant hotlines that allow the compliance officer or internal legal advisers to gain information from employees in confidence. A number of major jurisdictions (including the US and EU) do not currently take effective compliance programmes into account as a mitigating factor. Some have argued this approach is entirely justified and that compliance should not be rewarded where it has failed to prevent an infringement. ${ }^{100}$

Where firms do take internal compliance seriously, informant rewards offered by competition authorities risk creating a conflict between internal and external whistleblowing. For example, the US Dodd-Frank Act, rewards whistleblowers even if they bypass credible, functioning internal compliance programs. In doing this, the legislation may provide a further disincentive for companies to make significant investments in compliance programmes. ${ }^{101}$ Employees may be discouraged from reporting misconduct to their employer in a timely manner because of the prospect of receiving a large reward by approaching the authorities. ${ }^{102}$ In addition, linking the reward to the amount of money recovered may create an incentive for the individual to report an infringement later rather than sooner.

From an enforcement perspective the priority is uncovering an infringement, regardless of whether this is done by a whistleblower or a leniency application resulting from internal compliance efforts. The availability of an external whistleblower reward may even spur undertakings to take compliance more seriously - keen to ensure that any infringements are uncovered through leniency to the benefit of the whole firm. In addition, some academics suggest that the danger to compliance programmes has been overstated and that in reality there is little conflict between internal reporting and the very small minority of instances where employees will feel compelled to report serious misconduct to the authorities. ${ }^{103} \mathrm{An}$ empirical study of qui tam laws in the US showed that approximately 90 per cent of employees who would end up becoming external whistleblowers, initially attempted to raise their concerns internally. ${ }^{104}$

\footnotetext{
100 WPJ Wils, 'Antitrust Compliance Programmes and Optimal Antitrust Enforcement' (2013) Journal of Antitrust Enforcement 1(1) pp. 52-81.

${ }^{101}$ M Narine, 'Whistleblowers and Rogues: The Urgent Call for an Affirmative Defense to Corporate Criminal Liability' (2012) Catholic University Law Review Vol. 62, No.41

${ }^{102}$ R Howse and R Daniels, 'Rewarding Whistleblowers: The Costs and Benefits of an Incentive-Based Compliance Strategy' in RJ Daniels and R Morck (eds) Corporate Decision-Making in Canada (Calgary: University of Calgary Press 1995) p 526

${ }^{103}$ Schnell (n 4) p4

104 'Impact of Qui Tam Laws on Internal Compliance: A Report to the Securities Exchange Commission' (17 December 2010) National Whistleblowers Center. Available:

http://www.whistleblowers.org/storage/whistleblowers/documents/DoddFrank/nwcreporttosecfinal.pdf; MD Greenberg, 'For Whom the Whistle Blows: Advancing Corporate Compliance and Integrity Efforts in the Era of Dodd-Frank' (2011) RAND. Available:

http://www.rand.org/content/dam/rand/pubs/conf proceedings/2011/RAND CF290.pdf
} 
The effect of a whistleblower programme on compliance may the refore be neutral or even positive. Where firms have a culture of cartelisation prospective whistleblowers may prefer to report externally. They may fear that internal compliance mechanisms, such as compliance hotlines, will be abused by senior managers as a way of spotting trouble makers. They may also fear that their immediate managers and supervisors (involved in the cartel) will be believed over them. Where the cartel is being coordinated at a senior level, compliance hotlines may even be used as an opportunity to identify potential whistleblowers and intimidate them, pay them off, or move them to another part of the organisation $^{105}$

Significant Additional Resources - The cost of administering an informant reward scheme, and of paying out the bounties themselves, may require significant additional resources on the part of the competition authority. There is little evidence that the jurisdictions currently offering bounties are being inundated with information from informants, although rewards of the level suggested necessary in this chapter may produce a high volume of contacts. If a rewards scheme succeeds in uncovering more cartels that result in successful infringement decisions and fines, then these will outweigh any additional resources needed.

\section{Conclusion}

This chapter has reviewed the Korean innovation of providing rewards to individual whistleblowers in cartel cases and concludes that these schemes are a viable enforcement tool. With corporate fines approaching a ceiling due to political pressures and ability to pay considerations, and the use of criminal and other individual sanctions enjoying very limited success outside the US, informant rewards provide a way of increasing detection and deterrence without the need for significant additional resources. Informants will potentially uncover cartels not revealed through leniency or ordinary investigations. The use of informant rewards is arguably more legitimate than the use of leniency, because they benefit individuals and not whole undertakings, and may go to those not directly involved in an infringement. Although competition authorities would prefer to reward employees at the periphery of cartels, it is argued that informant rewards should not exclude individuals directly involved in an infringement. Insiders may be the only plausible whistleblowers or may have been pressured into getting involved in the infringement. One thing that cartels and organised crime have in common is the need for someone within the group of wrongdoers to provide sufficient evidence of what is going on. ${ }^{106}$

Measures designed to protect whistleblowers from the retaliatory actions of their employers do not go far enough and fail to create a sufficient incentive for individuals to come forward in the first place. The act of whistleblowing is associated with a number of

\footnotetext{
${ }^{105}$ Howse and Daniels (n 102) p536

${ }^{106}$ Howse and Daniels (n 102) p538
} 
very significant costs that must be compensated for by the informant reward. These include the risk of dismissal and lack of re-employment, not to mention the very serious repercussions for family, personal and social life. In order for the informant reward to counter these costs and risks, it must amount to a lottery win for the informant. These very large sums (a minimum of \$4-5 million in our hypothetical example) are justified if they result in successful investigations and cartel fines in cases that would otherwise go undetected. The levels of informant reward offered by the United Kingdom, Hungary and Pakistan appear particularly inadequate as an incentive to whistleblow, although Korea has shown that it is still possible to attract some informants with significantly lower sums.

The use of informant rewards is associated with a number of risks, but it is argued that these have been exaggerated or can be countered in a straight forwa rd way. The availability of large rewards risks creating a moral hazard problem, and so informants who were involved in setting up a cartel or who instigated the arrangements should be excluded from informant rewards. The danger of exaggerated or fraudulent claims (or of witness credibility in criminal enforcement systems) can be minimised by corroborating and supporting informant claims with information received through the leniency programme, once an investigation is under way. Firms in cartel cases show a very high propensity to cooperate once an investigation into their industry has been opened. The danger of conflict between informant reward schemes and firms' internal compliance programmes may be overstated. The availability of an informant reward scheme (externally) is likely to have a neutral effect or may even encourage the bolstering ogf internal compliance efforts.

The biggest challenge for informant reward schemes is providing prospective whistleblowers with sufficient certainty as to how they will be treated once they come forwa rd. Competition authorities rightly want to retain significant discretion so as to ensure rewards are not paid out without good justification. For the whistleblower, however, this discretion provides significant uncertainty. The danger that they will come forward only to be turned away or refused a reward because the case is not taken up, poses a significant disincentive. Once an informant has come forward, they have already put themselves at significant risk of retaliatory measures and the considerable costs associated with that. 